\title{
IN-VITRO EFFECTS OF CLOSTRIDIUM WELCHII TYPE-D EPSILON TOXIN ON GUINEA-PIG, MOUSE, RABBIT AND SHEEP CELLS
}

\author{
D. BUXTON \\ Department of Pathology, Moredun Research Institute, \\ 408 Gilmerton Road, Edinburgh, EH17 7JH

\section{Plates XXV-XXVII}

SOME bacterial products can affect the performance of the lympho-reticular system (see Stuart, 1970). Recently it has been shown that Vibrio cholerae enterotoxin can cause mitochondrial swelling in murine lymphoblastoid cells and murine plasmacytoid cells (Douglas, Zuckerman and Ooka, 1976). As Clostridium welchii type-D epsilon toxin shares some of the properties of $V$. cholerae enterotoxin (Buxton, 1978b) it was decided to investigate the effect of the epsilon toxin on the following cells: guinea-pig peritoneal macrophages (GPPM), pulmonary-alveolar macrophages and lymphocytes; mouse peritoneal macrophages and Lan Schultz ascites-tumour cells; rabbit peritoneal and pulmonary-alveolar macrophages; sheep lymphocytes.

\section{MATERIALS AND METHODS}

Clostridium welchii type-D epsilon toxin was prepared by dissolving epsilon prototoxin

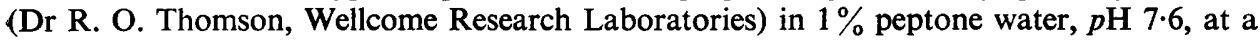
concentration of $100 \mu \mathrm{g}$ per ml. The solution was then incubated with trypsin $(0.25 \% \mathrm{w} / \mathrm{v})$ at $37^{\circ} \mathrm{C}$ for $45 \mathrm{~min}$. after which soybean trypsin inhibitor was added $(0 \cdot 25 \% \mathrm{w} / \mathrm{v})$.

Five 500-g Dunkin-Hartley guinea-pigs each received an intraperitoneal injection of $15 \mathrm{ml}$ of sterile liquid paraffin. Macrophages were harvested 7-10 days later by washing the peritoneum with Hanks' balanced salt solution (BSS) after the method of Fraser and Hancock (1977). The peritoneal macrophages were then suspended in Hanks' BSS at a concentration of approximately $20 \times 10^{6}$ per $\mathrm{ml}$.

Toxin and GPPM. Toxin $(0.1 \mathrm{ml})$ was added to aliquots of the GPPM suspension $(0.4 \mathrm{ml})$ to give concentrations of $0.001,0 \cdot 01,0 \cdot 1,1 \cdot 0$ and $10 \cdot 0 \mu \mathrm{g}$ per ml. Control cells were treated with $0.1 \mathrm{ml}$ of peptone water containing trypsin and trypsin inhibitor at the same concentration as in the aliquots of cells treated with $10 \mu \mathrm{g}$ of toxin. The suspensions were incubated for $30 \mathrm{~min}$. at $37^{\circ} \mathrm{C}$ and then two drops from each sample were mixed gently with eight drops of $0.1 \%$ Trypan blue in PBS and left to stand at room temperature for $5 \mathrm{~min}$. The cells in each sample were then resuspended and transferred to a counting chamber. Blue-stained cells were recorded as dead and unstained cells as live. All counts were corrected as in the following example to allow for the presence of dead cells not killed by toxin.

Cell suspension treated with toxin $10 \mu \mathrm{g}$ per ml: 516 cells counted; 386 dead $(74.8 \%)$. Cell suspension treated with peptone water: 366 cells counted; 10 dead $(2 \cdot 7 \%)$. Percentage of cells killed by toxin $=74 \cdot 8-2 \cdot 7=72 \cdot 1$. Percentage of live cells killed by toxin $=\frac{72 \cdot 1}{100-2 \cdot 7} \times \frac{100}{1}=74 \cdot 1$.

Received 30 Nov. 1977; accepted 16 Jan. 1978.

J. MED. MICROBIOL.-VOL. 11 (1978) 
For ultrastructural study, GPPM were washed three times in Hanks' BSS and divided into two aliquots. To one, $1 \mathrm{ml}$ of toxin was added to give a final concentration of $20 \mu \mathrm{g}$ per ml; to the other, $1 \mathrm{ml}$ of control diluent was added. Both tubes were incubated at $37^{\circ} \mathrm{C}$ for 30 min. and the percentage of dead cells in each tube was calculated. The cells were then centrifuged, the supernates discarded and $3 \%$ glutaraldehyde in $0 \cdot 1 \mathrm{M}$ phosphate buffer $p \mathrm{H} 7 \cdot 1$ was carefully layered on to the plugs and left for $10 \mathrm{~min}$. The plugs were removed, diced up into blocks and left overnight at $4^{\circ} \mathrm{C}$ in fresh fixative before being dehydrated in graded alcohols and embedded in Araldite. Sections were cut, and stained with lead citrate and uranyl acetate, and viewed and photographed in a Siemens Elmiskop 51.

Receptor sites. The method for demonstrating epsilon toxin-receptor sites has been described (Buxton, 1978a). GPPM were collected from four guinea-pigs and washed as described above, pooled and suspended in Hanks' BSS at a concentration of $4 \times 10^{7}$ cells per $\mathrm{ml} ; 99 \%$ of the cells were viable as revealed by the Trypan blue method. The suspension was divided into two portions; to one, formalinised epsilon prototoxin was added in a volume that produced a concentration of $6.66 \mathrm{mg}$ per $\mathrm{ml}$; to the other, the same volume of formalinised peptone water was added. After incubation of both preparations for $30 \mathrm{~min}$. at $37^{\circ} \mathrm{C}, 95 \%$ of the prototoxin-toxoid treated cells and $96.7 \%$ of the control cells were viable. The cells were then rinsed twice and resuspended in isotonic saline. The contents of both tubes were exposed to glutaraldehyde $1 \%$ for $10 \mathrm{~min}$., spun and rinsed twice in isotonic saline. The supernates were discarded and the pellets removed, stored in absolute alcohol overnight, processed and embedded in paraffin wax. Sections $(6 \mu \mathrm{m})$ were cut and treated by an immunoperoxidase technique (Buxton, 1978a). In addition, 12- $\mu \mathrm{m}$ sections were cut and mounted on Araldite cylinders; these were treated by the immunoperoxidase method as above and embedded in Araldite. From this material further $1-\mu \mathrm{m}$ sections were cut, mounted on glass slides and stained with Giemsa stain.

Toxin and other cells. Cell preparations from the peritoneal cavities of rabbits and mice were prepared as described for guinea-pig peritoneal macrophages. Guinea-pig and rabbit pulmonary-alveolar macrophages were flushed from the lungs with Hanks' BSS. Guinea-pig lymphocytes were obtained from the buffy coat of centrifuged blood samples and sheep lymphocytes were collected directly from a thoracic-duct cannula. Lan Schultz ascitestumour cells were collected from the ascitic fluid of mice that had received an intraperitoneal injection of the tumour cells 14 days earlier. The above preparations were treated in the same manner as the GPPM.

\section{RESULTS}

\section{Effect of toxin on GPPM}

The effect of the different concentrations of epsilon toxin on GPPM is shown in the table. Toxin had little measurable effect until a concentration of $0.2 \mu \mathrm{g}$ per $\mathrm{ml}$ was exceeded; mortality rose steeply to almost $80 \%$ with $10 \mu \mathrm{g}$ per ml.

Apart from killing cells, toxin also altered their morphology. The cytoplasm of the unstained live cells was very refractile and the plasma membranes were irregular whereas the blue-staining cells were generally much larger, less refractile and had a smoother outer margin that often appeared to be blistered.

Over $90 \%$ of the toxin-treated GPPM used in the ultrastructural studies were killed, whereas $98 \%$ of the control macrophages were viable after incubation. The morphology of the control cells was considered to be normal (fig. 1). The toxin-treated cells showed various degrees of degeneration. The less severely-affected cells contained shrunken rounded nuclei with ill-defined deposits of chromatin and their cytoplasmic membranes were less folded than those of the control cells. In more severely-affected cells the nuclear and 


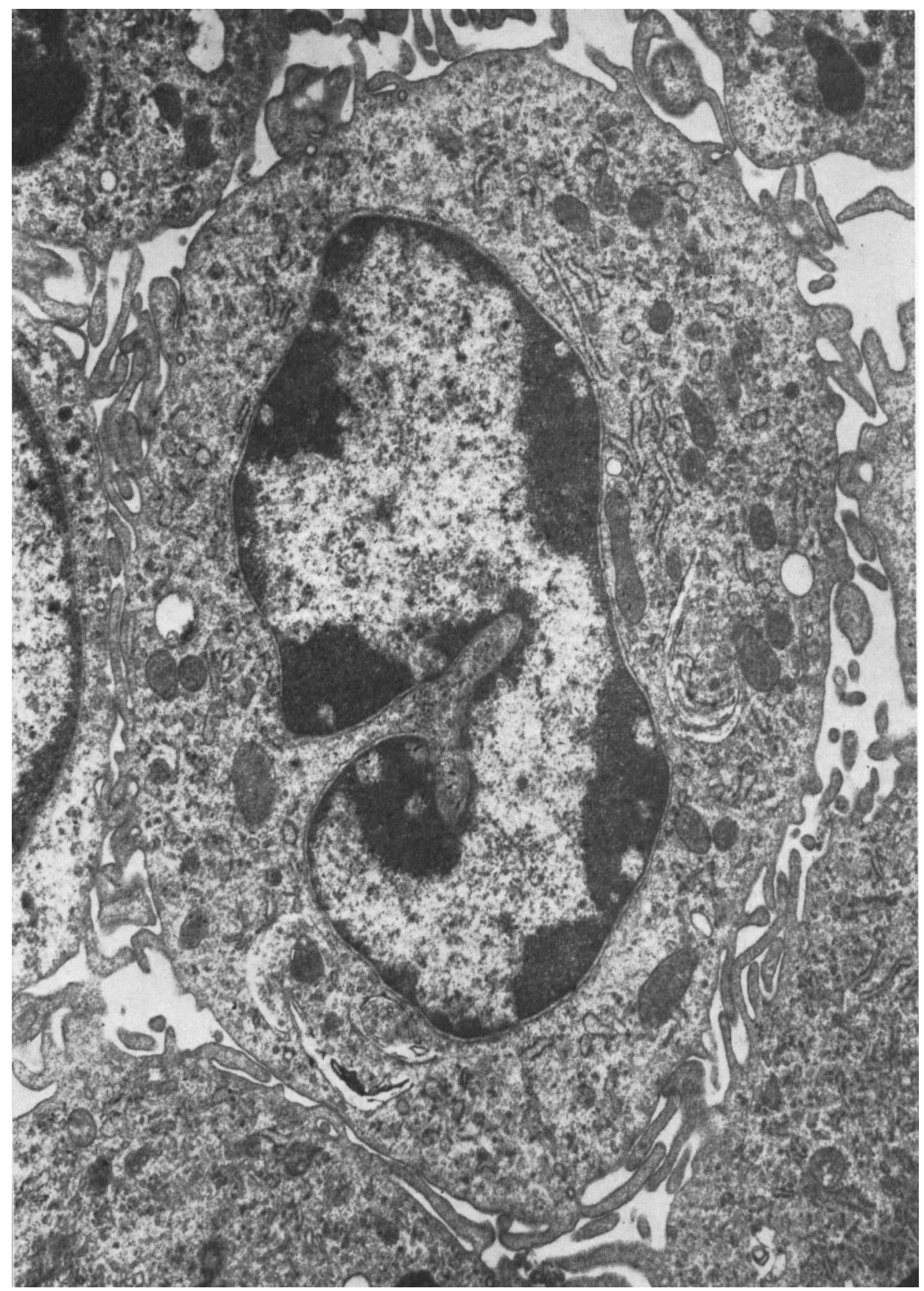

FIG. 1.-Control guinea-pig peritoneal macrophage (GPPM) showing normal morphology. Electronmicrograph (EM). $\times 13500$. 


\section{EFFECTS OF C. WELCHII EPSILON TOXIN ON CELLS}

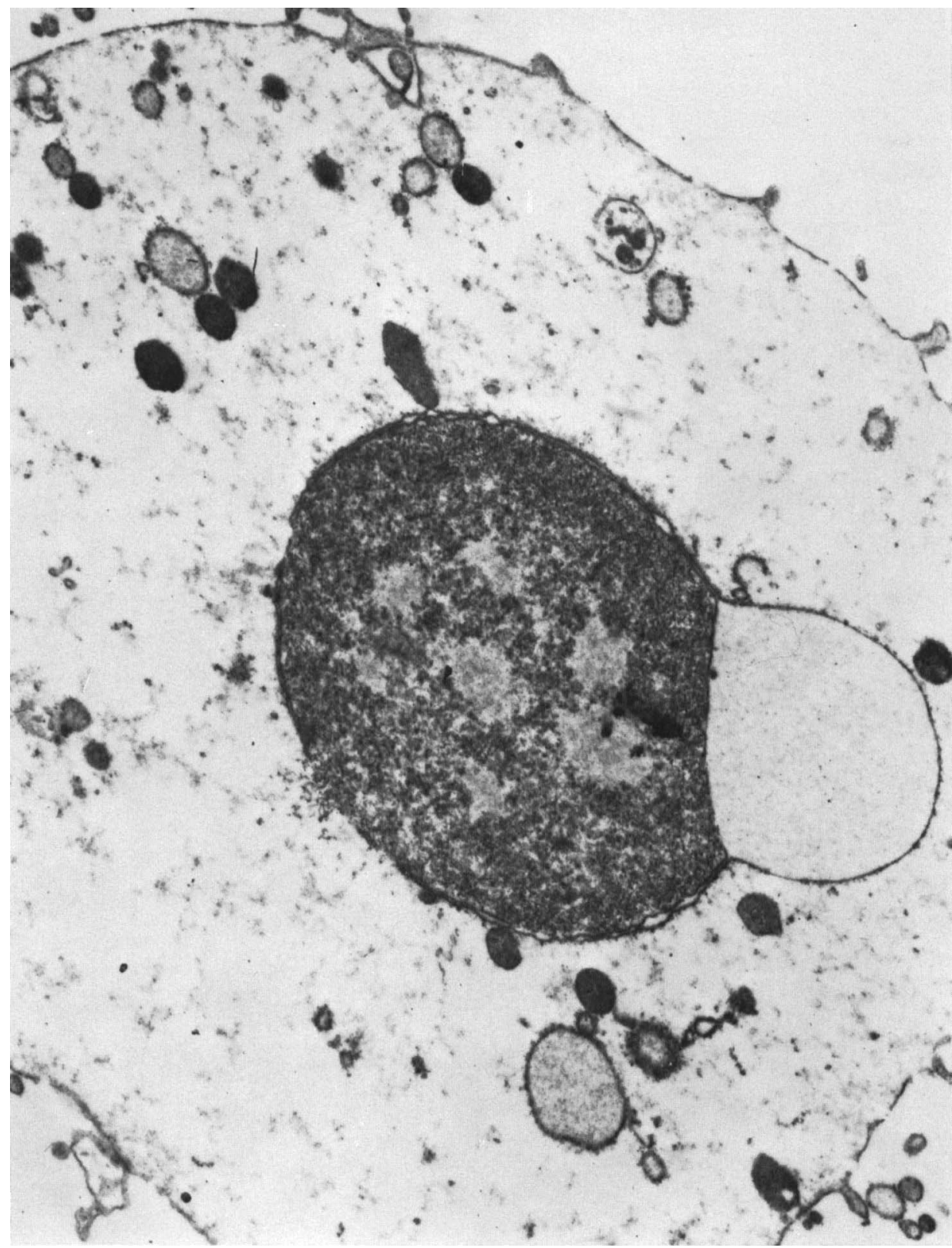

FIG. 2.-Epsilon toxin-treated GPPM showing blistering of nuclear membrane, ill-defined chromatin and swollen, structureless cytoplasm. EM. $\times 13500$. 
EFFECTS OF C. WELCHII EPSILON TOXIN ON CELLS

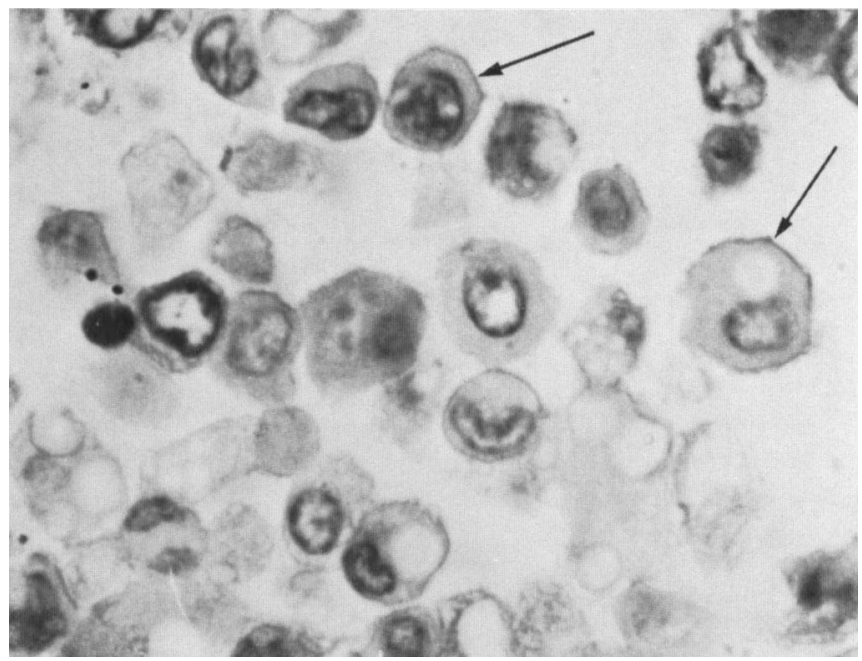

FIG. 3.-GPPM exposed to formalinised epsilon prototoxin and treated by the immunoperoxidase method to demonstrate the antigen [apparent as dark deposit around outer margins of cells (arrows)]. Araldite section. $\times 1600$.

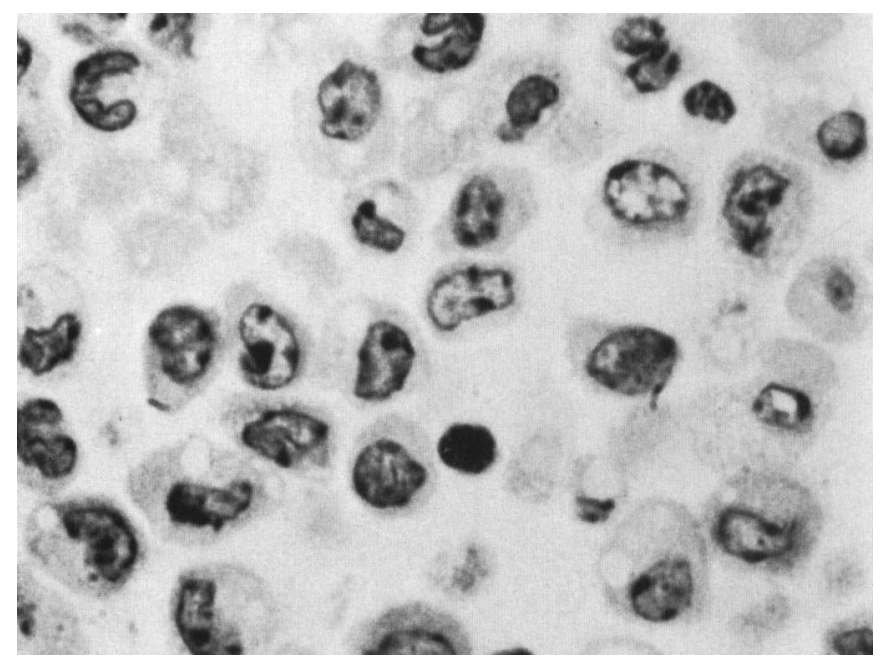

FIG. 4.--Control GPPM. No specific deposits of reaction product present. Araldite section. $\times 1600$. 
TABLE

The in-vitro effect of epsilon toxin on guinea-pig, mouse, rabbit and sheep cells

\begin{tabular}{|c|c|c|c|c|c|}
\hline $\begin{array}{c}\text { Animal } \\
\text { species }\end{array}$ & Type of cell & $\begin{array}{c}\text { Number } \\
\text { of } \\
\text { animals }\end{array}$ & $\begin{array}{l}\text { Incubation } \\
\text { time } \\
\text { (min.) }\end{array}$ & $\begin{array}{c}\text { Toxin } \\
(\mu \mathrm{g} \text { per } \mathrm{ml})\end{array}$ & $\begin{array}{l}\text { Percentage } \\
\text { of cells } \\
\text { killed }\end{array}$ \\
\hline Guinea pig & $\begin{array}{l}\text { Peritoneal macrophages } \\
\text { Peritoneal macrophages } \\
\text { Peritoneal macrophages } \\
\text { Peritoneal macrophages } \\
\text { Peritoneal macrophages } \\
\text { Pulmonary alveolar macrophages } \\
\text { Lymphocytes } \\
\text { Lymphocytes }\end{array}$ & $\begin{array}{l}5 \\
5 \\
5 \\
5 \\
5 \\
2 \\
1 \\
1\end{array}$ & $\begin{array}{r}30 \\
30 \\
30 \\
30 \\
30 \\
180 \\
30 \\
60\end{array}$ & $\begin{array}{l}0 \cdot 001 \\
0.01 \\
0 \cdot 1 \\
1 \cdot 0 \\
10 \cdot 0 \\
20 \\
20 \\
20\end{array}$ & $\begin{array}{c}3 \\
4 \\
5 \\
33 \\
79 \cdot 5 \\
0 \\
0 \\
0\end{array}$ \\
\hline Mouse & $\begin{array}{l}\text { Peritoneal macrophages } \\
\text { Peritoneal macrophages } \\
\text { Lan Schultz ascites-tumour cells } \\
\text { Lan Schultz ascites-tumour cells }\end{array}$ & $\begin{array}{l}2 \\
3 \\
1 \\
1\end{array}$ & $\begin{array}{r}30 \\
165 \\
150 \\
180\end{array}$ & $\begin{array}{l}20 \\
20 \\
20 \\
20\end{array}$ & $\begin{array}{l}0 \\
0 \\
0 \\
0\end{array}$ \\
\hline Rabbit & $\begin{array}{l}\text { Peritoneal macrophages } \\
\text { Peritoneal macrophages } \\
\text { Peritoneal macrophages } \\
\text { Peritoneal macrophages } \\
\text { Pulmonary alveolar macrophages }\end{array}$ & $\begin{array}{l}2 \\
2 \\
3 \\
1 \\
2\end{array}$ & $\begin{array}{r}30 \\
60 \\
90 \\
150 \\
150\end{array}$ & $\begin{array}{l}20 \\
20 \\
20 \\
20 \\
20\end{array}$ & $\begin{array}{c}11 \cdot 2 \\
26 \cdot 8 \\
40 \cdot 3 \\
45 \cdot 5 \\
0\end{array}$ \\
\hline Sheep & Lymphocytes & 1 & 30 & 20 & 0 \\
\hline
\end{tabular}

cytoplasmic membranes appeared "blistered" and were sometimes discontinuous (fig. 2). Intracytoplasmic organelles were almost completely lost.

Cells treated by the immunoperoxidase method after exposure to formalinised epsilon prototoxin showed clearly defined brown lines of horseradishperoxidase reaction product closely adherent to their outer margin (fig. 3). These deposits were not seen in duplicate control sections (fig. 4).

\section{Effect of toxin on cells other than GPPM}

The results are summarised in the table. Toxin at concentrations as high as $20 \mu \mathrm{g}$ per $\mathrm{ml}$ had no effect on any preparation except the rabbit peritoneal macrophages which, when compared with the GPPM preparations, were not nearly as susceptible. Higher concentrations of toxin and prolonged periods of incubation were necessary to produce a mortality of over $40 \%$.

\section{Discussion}

It has been shown that epsilon toxin readily kills guinea-pig peritoneal macrophages (GPPM) in vitro but that guinea-pig lymphocytes and pulmonaryalveolar macrophages remain viable after similar treatment. This difference in susceptibility between cells of the same type within a species was also encountered in the rabbit, although rabbit peritoneal macrophages were much less susceptible than those of the guinea-pig.

Guinea-pig peritoneal macrophages were shown to bind formalinised epsilon prototoxin on their outer surfaces and as it has been shown that this antigen 
competes for the same receptor sites as epsilon toxin (Buxton, 1976) it is considered that the reaction product was located on the epsilon-toxin receptor sites.

Formalinised epsilon prototoxin was not tested for its ability to bind to any of the other cells used in this study so it is not possible to say whether the lack of susceptibility of, for example, guinea-pig and rabbit pulmonary-alveolar macrophages was due to the absence or masking of suitable receptor sites. The inability of epsilon toxin to kill these cells does not necessarily mean that receptor sites were not available: when Vibrio cholerae toxin is incubated with murine lymphoblastoid or plasmacytoid cells mitochondrial swelling results, but this does not happen when the toxin is incubated with rabbit pulmonaryalveolar macrophages; however the toxin causes an increase in the intracellular cyclic adenosine $3^{\prime}, 5^{\prime}$-monophosphate levels in all three cell types and this suggests the presence of suitable receptor sites in each (Douglas et al., 1976).

The present evidence clearly indicates that $C$. welchii type-D epsilon toxin binds to the surface of GPPM in vitro and kills them. The mechanism whereby epsilon toxin causes damage is unknown but it may, as demonstrated for $V$. cholerae toxin, be mediated through an adenyl cyclase-cAMP system (Buxton, 1978b).

\section{SUMMARY}

Epsilon toxin, at relatively low concentrations, killed guinea-pig peritoneal macrophages in vitro. The cells became swollen, the nuclear and cytoplasmic membranes "blistered" and discontinuous, and the cytoplasm appeared structureless. Formalinised epsilon prototoxin was shown to bind closely to the outer surface of the cells and it is concluded that this site represents the location of the receptors for epsilon toxin.

In addition the toxin at higher concentrations killed rabbit peritoneal macrophages after increased periods of incubation, but had no demonstrable effect on other cells from guinea-pigs, rabbits, mice and sheep.

I am grateful to Dr R. M. Barlow and Professor J. G. Collee for helpful advice and Mrs J. Finlayson and Mr J. Wight for technical assistance.

\section{REFERENCES}

Buxton, D. 1976. Use of horseradish peroxidase to study the antagonism of Clostridium welchii ( $\mathrm{Cl}$. perfringens) type $\mathrm{D}$ epsilon toxin in mice by the formalinized epsilon prototoxin. J. comp. Path., 86, 67.

Buxton, D. 1978a. The use of an immunoperoxidase technique to investigate by light and electron microscopy the sites of binding of Clostridium welchii type-D epsilon toxin. J. med. Microbiol., 11, 289.

BuXToN, D. $1978 b$. Further studies on the mode of action of Clostridium welchii type-D epsilon toxin. J. med. Microbiol., 11, 293.

Douglas, S. D., Zuckerman, S. H. AND OOKA, M. P. 1976. Effects of cholera exotoxin on the mitochondrial morphology of lymphoid cells and mononuclear phagocytes. Lab. Invest., 35, 607.

Fraser, H. AND HANCOCK, P. M. 1977. An investigation of the macrophage electrophoretic mobility test in the diagnosis of scrapie in sheep. J. comp. Path., 87, 267.

StUART, A. E. 1970. The reticulo-endothelial system, Edinburgh and London. 